\title{
Türkiye'de toprak parçalanması ve miras hukuku
}

\author{
Soil fragmentation in Turkey and law of succession
}

\author{
Cengiz SAYIN ${ }^{1}$, Mehmet ALTUNKAYA ${ }^{2}$, Yavuz TAŞÇIOĞLU ${ }^{1}$, Oya SAV $^{1}$, İpek KAVASOĞLU ${ }^{1}$ \\ ${ }^{1}$ Akdeniz Üniversitesi, Ziraat Fakültesi, Tarım Ekonomisi Bölümü, 07070 Antalya \\ ${ }^{2}$ Akdeniz Üniversitesi, Hukuk Fakültesi, 07070 Antalya \\ Sorumlu yazar (Corresponding author): C. Sayın, e-posta (e-mail): csayın@akdeniz.edu.tr
}

\section{MAKALE BİLGİSİ}

Alınış tarihi 01 Temmuz 2015

Düzeltilme tarihi 07 Kasım 2017

Kabul tarihi 07 Kasım 2017

\section{Anahtar Kelimeler:}

Tarım

Miras

Toprak parçalanması
ÖZ

Cumhuriyetten bu yana, mevcut Miras Yasası'nda yer alan özel miras düzenlemelerin tarım işletmelerinin ve tarım topraklarının bölüşümünü engelleyemediği görülmektedir. Bundan dolayı, tarımda miras ile ilgili yasal yapının yeniden ele alınması gerekliliği ortaya çıkmıştır. Bu çalışmada Türkiye'de son yıllarda tarımda miras hukukunda yaşanan gelişmeler incelenmiş olup miras yolu ile arazi bölünmeleri konusunda bütünlük sağlanarak, Medeni Kanun kapsamında yer alan tarımsal taşınmazlar ile ilgili düzenlemelerin 2014 yılında yürürlüğe giren 6537 sayılı kanununun içine taşınarak mülga haline geldiği belirlenmiştir.

\section{ARTICLE INFO}

Received 01 July 2015

Received in revised form 07 November 2017 Accepted 07 November 2017

\section{Keywords:}

Agriculture

Inheritance

Soil fragmentation

\begin{abstract}
Beginning from the foundation of Republic, specific inheritance provisions in Civil Law are unable to prevent the fragmentation of agricultural enterprises and agricultural lands. To this respect, necessity of re-addressing of the legal structure on inheritance in agriculture has arisen. In this study, when the recent improvements in the Law of Succession in Turkey are taken into consideration; with the integrity on land fragmentation by inheritance, it is determined that the provisions related to agricultural immovable property in Civil Law has been transferred to 6537 numbered law which went into effect in 2014 as remained repealed.
\end{abstract}

\section{Giriş}

Tarım işletmelerinin ekonomik bütünlüğünün korunması, tarımda verimliliğin sağlanması açısından oldukça önemlidir. Türkiye'de tarımsal işletmelerin ve bu işletmelere ait tarım topraklarının parçalanarak küçülmesi, tarımda verimliliğin azalmasına ve üretim miktarında kaybın yaşanmasına sebep olmaktadır. Türkiye'de toprakların parçalı yapıda olmasının en önemli nedeni miras yoluyla yaşanan parçalanmalardır. Tarım topraklarının ve tarımsal işletmelerin bölüşümü ile ilgili yasal düzenlemelerin yetersiz olması ve nüfus baskısı yaşayan tarım topraklarının hisseli veya bölünerek satışının yapılması tarımsal arazilerde faaliyetlerin sürdürülebilirliğini etkilemektedir. Tarımda verim kaybına neden olan bu durum, yapısal düzenleyici mevzuatın gerekliliğini ortaya koymaktadır. Türkiye'de tarımsal arazinin korunması ile ilgili çıkarılan yasal düzenlemelerde toprağın edinimi, kullanılması ve tasarrufuyla ilgili esaslar özel hukuk kapsamında belirlenmeye çalışılırken mülkiyet ekseninin ise tarımsal işletmelerden tarımsal arazilere kaydığı görülmektedir.

\section{Materyal ve Yöntem}

Çalışmada materyal olarak ikincil verilerden faydalanılmıştır. İşletme göstergeleri ile ilgili verilere Türkiye İstatistik Kurumu (TÜIK), Gıda, Tarım ve Hayvancılık Bakanlığı (GTHB) ve Kalkınma Bakanlığı kaynaklarından ulaşılmıştır. Hukuki durumu inceleyebilmek için ilgili yasalar ve bilimsel araştırmalardan yararlanılmıştır.

\section{Bulgular}

\subsection{Tarımsal İşletme Kavramı ve Toprak Parçalanması}

\subsubsection{Türkiye'de Tarım İşletmelerinin Hukuki Çerçevesi}

Tarımsal işletme; üretim faktörlerini kullanarak tarımsal üretim faaliyeti sürdürülen, sermaye öğeleri bulunan ve belirli bir büyüklüğe sahip olan ekonomik birimlere denir (Aksoy 1984). 
Tarımsal işletme tanımından anlaşılacağı gibi bir tarımsal işletmenin sahip olması gereken temel özellikler veya öğelerin başında; belirli sermaye unsurlarına sahip olması, tarımsal faaliyette bulunması ve belirli bir büyüklükte (ekonomik ölçek) olması gelmektedir. Tarım işletmelerinde olması gereken bu özellikler, bir tarım işletmesinin miras yolu ile bölüşümünü de engelleyen kriterler arasındadır. Özel miras kurallarına tabi olan tarım işletmelerinin bölüşümü konusunda kararı vermek söz konusu olduğunda tarım işletmesi kavramının mevcut yasal yapı içerisinde tanımlanmış olması gerekmektedir. Ancak uzun yıllardır böyle bir tanımlamanın yapılmamış olması tarımda miras bölüşümünün, tarım işletmesinin tüm sermaye varlıkları ile birlikte bütününü konu edinmesi gerekirken maalesef sadece toprak bölüşümü üzerinde uygulamanın yoğunlaştığı görülmüştür.

Tarımsal işletmenin en kapsamlı tanımı, 2006 yılında yürürlüğe giren Tarım Kanunu'nda yapılmıştır. Kanuna göre; "üretim faktörlerini kullanarak bitkisel ve/veya hayvansal ve/veya su ürünlerinin üretimi için tarımsal faaliyet yapan veya söz konusu tarımsal faaliyete ilave olarak işleme, depolama, muhafaza ve pazarlamaya yönelik faaliyetlerde bulunan işletme" tarımsal işletme olarak tanımlanmaktadır (Anonim 2006). Türkiye İstatistik Kurumu'na (TÜİK) bağlı tarımsal işletmelerle ilgili bir veritabanı kurmayı amaçlayan Tarımsal İşletme Kayıt Sistemi'nde (TIKKAS) yer alan tanımlamaya göre ise; "yasal durumu ne olursa olsun, sahip olduğu, ortakçıllk, yarıcılık ya da kiralama şeklinde işlediği arazinin büyüklüğüne bakılmaksızın kendi adına bitkisel üretim yapan ya da küçükbaş veya büyükbaş hayvan besleyen veya hem bitkisel üretim hem hayvancılık yapan tek yönetim altındaki ekonomik birim" olarak ifade edilmektedir (TIKKAS 2015).

Türkiye'de tarım işletmelerinin küçük ve parçalı bir yapıda olması, tarımın yapısal sorunları arasında yer almaktadır ( $\underline{\text { Sayın }}$ 2015). AB ülkelerinde tarımda miras ile ilgili yasal yap1, tarımsal işletmeyi bir bütün olarak ele almakta ve mirasçılar arasında eşit şekilde paylaşım gibi fiziki bir bölüşümü öngörmemektedir. Oysa Türkiye'deki 2014 yılında yürürlüğe giren 6537 Say1lı Kanun öncesinde Medeni Kanun'da yer alan düzenlemeler, tarımsal işletmeyi tüm varisler arasında pay edilebilen bir kalıt olarak tanımlamaktadır. Öte yandan bir tarımsal işletmenin en önemli sabit sermaye varlığ öğesinin daha fazla parçalanmasını önleyecek yasal düzenlemelerin gecikmeli olarak hayata geçirilmesi de Türkiye'de toprak parçalanmasının hızla devam ettirilmesine ortam hazırlamıştır.

\subsection{Türkiye'de Tarım Arazilerinin Parçalılık Durumu}

Toprak parçalanması veya parçalılığı; bir tarımsal işletmedeki mevcut toprakların tek bir bütün (tek parça) halinde kalmayıp birkaç parçaya (parsele) bölünmesi durumudur. Parçalanmanın devamı veya küçülerek giderek artış göstermesi toprağında ekonomik olarak işletilmesini engellemekte ve verimliliği de olumsuz etkilemektedir.

Cumhuriyetten bu yana, mevcut Miras Yasası'nda yer alan tarım işletmelerinin miras yolu ile bölüşümünü konu alan özel miras düzenlemeleri tam olarak işletilememiş ve tarım toprakları maalesef uzun yıllar boyunca bölünerek devam ede gelmiştir.

Türkiye'de tarım işletmeleri ve arazi kullanım durumlarına göre 2001 yılında yapılan Tarım Sayımı'nda 3 milyon dolayında tarım işletmesinin olduğu belirlenmiştir. Tarımsal işletmelerle ilgili parçalılık durumlarını gösteren 2001 Genel Tarım Sayımı (GTS) sonuçlarına göre, işletme başına ortalama 4.1 adet parsel düşmekte ve ortalama parsel büyüklüğü ise 1.5 hektardır (Cizelge 1). Tarım işletmeleri, işletme büyüklüğü ve tarım arazisi parça sayısına göre incelendiğinde işletmelerin \% 21.6'sının 4-5 parçalı yapıya sahip olduğu görülmektedir (TÜIK 2006).

Türkiye'de 1950'li yıllardan itibaren ortalama işletme büyüklüğü azalırken 1990'larda 5.9 hektar olan işletme büyüklüğü 2001 yılına gelindiğinde 6.1 hektar olarak hesaplanmıştır (Cizelge 2).

Türkiye'de Çiftçi Kayıt Sistemi verilerine göre 2002 yılından itibaren verilen ortalama işletme büyüklüklerinde artı̧̧ yaşanırken 2011 yılında ortalama işletme büyüklüğü 6.8 hektara ulaşmıştır (Anonim 2014).

Arazi kullanımında en yaygın tasarruf şekli olarak yalnız kendi arazisini işletenler yer alsa da yıllar itibariyle işletilen alan paylarının giderek azaldığı görülmektedir (Çizelge3).

Çizelge 1. İşletme büyüklüklerine göre ortalama parsel sayısı ve ortalama parsel büyüklüğü.

Table 1. Average partial number and size as per enterprise size.

\begin{tabular}{ccc}
\hline $\begin{array}{c}\text { İșletme Büyüklüğü } \\
\text { (Ha) }\end{array}$ & $\begin{array}{c}\text { Ortalama Parsel } \\
\text { Sayısı (Adet) }\end{array}$ & $\begin{array}{c}\text { Ortalama Parsel } \\
\text { Büyüklüğü (Ha) }\end{array}$ \\
\hline$<5$ & 3.3 & 0.6 \\
$5.0-9.9$ & 5.1 & 1.3 \\
$10.0-19.9$ & 5.7 & 2.3 \\
$20.0-49.9$ & 6.5 & 4.2 \\
$\geq 50$ & 7.8 & 12.3 \\
Toplam (Adet, Hektar) & 4.1 & 1.5 \\
\hline
\end{tabular}

Kaynak: Anonim 2014.

Çizelge 2. GTS sonuçlarına göre işletme sayısı, arazi miktarı ve ortalama işletme büyüklüğü.

Table 2. Enterprise number, land and average enterprise size as per GTS results.

\begin{tabular}{cccc}
\hline Yılı & $\begin{array}{c}\text { İşletme Sayısı* } \\
\text { (Bin Adet) }\end{array}$ & $\begin{array}{c}\text { Arazi } \\
\text { (Bin Ha) }\end{array}$ & $\begin{array}{c}\text { Ortalama İşletme } \\
\text { Büyüklüğ̈̈ (Ha) }\end{array}$ \\
\hline $\mathbf{1 9 5 0}$ & 2.528 & 19.452 & 7.7 \\
$\mathbf{1 9 8 0}$ & 3.559 & 22.764 & 6.4 \\
$\mathbf{1 9 9 1}$ & 3.967 & 23.451 & 5.9 \\
$\mathbf{2 0 0 1}$ & 3.022 & 18.435 & 6.1 \\
\hline
\end{tabular}

Kaynak: Anonim 2014.

*Toprağı olmayan işletmeler sayıya dahil edilmemiştir.

\subsubsection{Tarımsal Arazilerin Parçalanma Nedenleri}

Türkiye'de tarım toprağının başlıca parçalanma nedenlerinin başında, miras yoluyla bölüşümleri gelmektedir. Bunu, bir kısım üreticilerinin ekonomik zorluklar nedeniyle arazilerini satışa sunması izlemektedir. Hisseli ve bölünerek yapılan tarım topraklarının alım ve satımında yasal denetimin olmaması da parçalanmada etkili olmaktadır (Ekinci ve Sayılı $\underline{2010})$.

Parçalanmaya sebep olan diğer faktörler arasında ise kamulaştırma faaliyetleri ve arazi tasarruf şekilleri gibi nedenler de yer almaktadır (Demirtaş ve Sarı 2003). 
Çizelge 3. Arazinin tasarruf şekline göre işletme sayısı ve işledikleri arazi miktarı (\%).

Table 3. Enterprise number and land as per usage (\%).

\begin{tabular}{|c|c|c|c|c|c|c|}
\hline \multirow{2}{*}{ TASARRUF ŞEKLI } & \multicolumn{2}{|c|}{1991} & \multicolumn{2}{|c|}{2001} & \multicolumn{2}{|c|}{2006} \\
\hline & İşletme Sayısı & İşletilen Alan & İşletme Sayısı & İşletilen Alan & İşletme Sayısı & İşletilen Alan \\
\hline $\begin{array}{l}\text { Yalnız Kendi Arazisini } \\
\text { İşletenler }{ }^{1}\end{array}$ & 92.6 & 89.3 & 85.9 & 77.8 & 85.1 & 71.4 \\
\hline $\begin{array}{l}\text { Kendi Arazisi Yanında Dışarıdan } \\
\text { Arazi Tutanlar }\end{array}$ & 5.8 & 9.8 & 10.5 & 18.6 & 12.7 & 26.4 \\
\hline $\begin{array}{l}\text { Yalnız Kiracılık ile Arazi } \\
\text { İşletenler }\end{array}$ & 1.2 & 0.6 & 1.8 & 1.7 & 1.6 & 1.5 \\
\hline $\begin{array}{l}\text { Yalnız Ortakçılık ile Arazi } \\
\text { İşletenler }\end{array}$ & 0.3 & 0.3 & 1.3 & 1.4 & 0.4 & 0.4 \\
\hline $\begin{array}{l}\text { Diğer Şekillerde Arazi İşletenler } \\
\text { (Bedelsiz, Hibe) }\end{array}$ & 0.1 & 0.1 & 0.3 & 0.3 & 0.1 & 0.1 \\
\hline $\begin{array}{l}\text { İki ve Daha Fazla Tasarruf } \\
\text { Şekliyle Arazi İşletenler }\end{array}$ & 0.1 & 0.0 & 0.2 & 0.3 & 0.1 & 0.2 \\
\hline TOPLAM & 100 & 100 & 100 & 100 & 100 & 100 \\
\hline
\end{tabular}

Kaynak: Anonim 2014.

${ }^{1}$ Zilyetliğe dayalı olarak arazi işleten işletmeler dahil edilmiştir.

\subsubsection{Tarımsal Arazi Parçalanmasının Sakıncaları}

Türkiye'de toprak üzerindeki nüfusun giderek artmasıyla beraber tarımda parçalanmalar yaşanırken tarımsal işletme ölçeğinin küçük olması ve bu işletmelere ait arazilerin dağınık ve çok sayıda parçadan oluşması tarımsal arazilerin etkin ve sürdürülebilir kullanımlarını engellemektedir.

Arazi parçalanmalarının tarıma olan yansımaları incelendiğinde, parçalanmanın en çok verim üzerine olumsuz etkisinin olduğu görülmektedir. Arazi kullanımı yönüyle ise parçalanma; tarımsal faaliyetin yapılmasını güçleştirirken, çayır ve meraların muhafazasını ve otlayan hayvanların kontrolünü zorlaştırmaktadır.

Parçalanmanın bir diğer önemli etkisi, işçilik maliyetlerini arttırmasıdır. Parçalılığın çok fazla olduğu arazilerde işçilik giderleri toplu olan arazilere oranla daha yüksek olmaktadır (Anonim 2014).

\subsection{Tarım Topraklarının Parçalanmasını Önleyici Düzenlemeler ve Miras Yasası}

Sürekli artan nüfus ve beslenme ihtiyac1, her ülkenin kendi koşullarına göre önlem almasına neden olmaktadır. En önemli konu olarak, beslenmenin devamlılığının sağlanması ve bu amaçla tarımsal üretim faaliyetinin sürdürülmesi öne çıkmaktadır. $\mathrm{Bu}$ da ancak tarım topraklarının varlığının korunmasına ve tarımsal faaliyet gerçekleştirecek ölçeklerde olmasına bağlıdır. $\mathrm{Bu}$ nedenle, tarım topraklarının parçalanmasının önlenmesi ve yeter gelir sağlayacak ölçeklerde tutulması önemli konu olarak öne çıkmaktadır.

Türkiye'de tarım topraklarının parçalanmasını ve optimum ölçeklerden uzaklaşmasını önleyici hukuki yapı içerisinde miras belirleyici olmaktadır. Medeni Kanun içerisinde Miras Yasası ile pek çok düzenleme öngörülmüş olup zaman içinde güncelleme yaşanmıştır. Miras Yasası, toprakla ilgili parçalanma önleyici Eşya Hukuku kapsamında çeşitli özel düzenlemeler yanında, Kamu Hukuku alanında gerçekleştirilen Kanun ve Yönetmelikleri gündeme getirilmiştir. Tarımda mirasla ilgili yasal yapılanma sirasıyla;

$\begin{array}{ll}\checkmark & \text { Medeni Kanun, No: } 743-1926 \\ \checkmark & 1961 \text { Anayasası } \\ \checkmark & 1982 \text { Anayasası }\end{array}$

$\checkmark \quad$ Medeni Kanun, No: 4701-2001 (Md.973-1030) (Resmi Gazete 2001)

$\checkmark$ Toprak Koruma ve Arazi Kullanımı Kanunu, No: 5403 - 05 (Resmi Gazete 2005a)

$\checkmark$ Toprak Koruma ve Arazi Kullanımı Kanununda Değişiklik Yapılması Hakkında Kanun, No: 5578-2007 (Resmi Gazete 2007a)

$\checkmark$ Toprak Koruma ve Arazi Kullanımı Kanununda Değişiklik Yapılması Hakkında Kanun, No: 6537-2014 (Resmi Gazete 2014a)

$\checkmark$ Tarımsal Arazilerin Mülkiyetinin Devrine İlişkin Yönetmelik - 2014 (Resmi Gazete 2014b) şeklindedir.

\subsubsection{Medeni Kanun'da Tarımsal İsletme ve Toprak}

Miras Yasası kapsamında "toprak" ve "tarımsal işletme" konusu ayrıştırılmamıştır. $\mathrm{Bu}$ yasa ağırlıklı olarak toprak kavramı üzerinde durmuş, işletme bölüşümü uygulamasını sağlıklı olarak ele almamıştır.

\subsubsection{1926 Tarihli Medeni Kanun ve Miras Yasast}

Cumhuriyet sonrasında, tarım hukukunun önemli konuları arasında yer alan toprak hukukunun ele alındığ 1 temel yasal düzenlemelerin başında 1926 yılında yürürlüğe giren 753 Sayılı Medeni Kanun gelmektedir. Medeni Kanun'nun 597-602. maddeleri arasında "Ziraat İşleri”" başlığı tarımsal işletmelerin veya günümüzdeki uygulama şekliyle tarım topraklarının miras yoluyla paylaşımı konuları yer almaktadır. Bu kapsamda;

$\checkmark$ Tarım işletmelerinin paylaştırma dışında bırakılması,

$\checkmark \quad$ Özgülemenin bir kişiye yapılabilmesi için gerekli koşulları,

$\checkmark \quad$ Diğer mirasçıların paylarının ödenmesi alt başlıkları üzerinde önemle durulmaktadır.

Örneğin, miras kalan kalıtta (terekede) işletilen ekonomik bir bütünlüğ̈ olan zirai mallar miras birakanın ailesinden (altsoyu ve eşine) işletmeye ehil görülen mirasçıya tahsis edilir. Ancak mirasçılar arasında anlaşma sağlanamadığı veya birden fazla mirasçının işletmeye talip olması halinde, mirasçıların mahkemeye gidebilecekleri belirtilmiştir. Mahkeme sonucunda hakim, işletmeyi bir tek mirasçıya veya birden çok mirasçıya da özgüleyebilir, işletmenin satışına karar verebilir (Resmi Gazete 
1926a). İşletmenin bir kişiye özgülenmesi durumunda; malların değerlerinin tespiti, diğer mirasçıların ödenmesi gereken payları açısından önemlidir (Aksoy 1984). Özgüleme yapılan mirasçının, diğer mirasçıların paylarının karşılığını ödeyebilmesi için işletmenin dörtte üçünden fazlasını teminat göstermek mecburiyetinde kalırsa, mirasın paylaşımını erteleyebilir. Bu durumda payların paylaşımı yapılıncaya kadar kazanç payı dağıtan aile malları ortaklığı kurulabilmektedir (Resmi Gazete 1926b).

Özgüleme yapılan mirasçı, diğer mirasçıların hisselerinin bedellerini ödeyebilecek duruma gelirse, mirasçılardan her biri aile malları ortaklığının feshini ve paylarının ödenmesini isteyebilir (Resmi Gazete 1926c).

\subsubsection{2001 Tarihli Medeni Kanun ve Miras Yasası}

Türk Medeni Kanunu, günümüz koşullarına uyum sağlayabilmesi için 2001 yılında yeniden düzenlenerek 4721 Sayılı Kanun ile tekrar yürürlüğe girmiş, tarımı ilgilendiren miras ile ilgili kısımlar 659-668. maddeleri arasında düzenlenmiştir.

1926 yılında yürürlüğe giren Medeni Kanun'un ilk halinde tarımda mirasa konu olan tarımsal varlığa (zirai mallar) ait miras ile ilgili hükümler ele alındığında; mirasın kime özgüleneceği, özgüleme işleminden sonra diğer mirasçıların haklarının ne olacağı konularının işlendiği görülmektedir. Her ne kadar tarımsal işletme ile ilgili bölüşümü engellemek için genel miras hukuku içinde "taksimden istisna" bırakarak ayrı bir düzenlemeye yer verilse de, Medeni Kanun'un öngördüğü eşit paylaşımdan tarımsal işletmeler ve bu işletmelere ait tarımsal topraklarda parçalanmalar yaşanmaya devam etmiştir.

Yeniden düzenleme yapılarak yürürlüğe giren Medeni Kanun'un tarımla ilgili miras hükümlerinde bir önceki kanuna göre daha açık bir dil kullanılmış, "zirai mallar" yerine "tarım işletmesi” kavramı yerleştirilmiştir. Öne çıkan diğer bir ifade ise; miras kalan kalıtta (terekede) ekonomik bütünlüğe ve yeterli tarımsal varlı̆ga sahip bir tarım işletmesinin olmasıdır (Resmi Gazete 2014c). Kanunun önceki halinde bahsi geçen zirai malların ne olduğu diğer bir deyişle mirasa konu olan varlığın tanımının yapıldığı anlaşılmaktadır. Yeni yasanın içine mirasçılarla ilgili hakların aynen taşındığı görülürken bu maddelere ek olarak "diğer mirasçıların paylarının mirasçı irat (alacak) senediyle karşılanması” kısmı getirilmiştir.

Medeni Kanun içinde yer alan tarımda miras hukukunu şekillendiren temel yasal düzenlemelerin tarımda mirasla ilgili ihtiyaçlara cevap verememesi nedeniyle, tarımda mirasla ilgili konularda bütünlük sağlanması amacıyla Medeni Kanun içinde yer alan tarımsal taşınmazlar ile ilgili düzenlemeler 2014 yılında yürürlüğe giren 6537 Sayılı Toprak Koruma ve Arazi Kullanımı Kanunu'nda Değişiklik Yapılması Hakkında Kanun içine taşınarak yeniden düzenlenmiştir.

\subsection{Anayasal Düzenleme Iç̧inde Toprak Mülkiyeti}

Toprağın mülkiyetine ilişkin hükümlerin yer aldığı en temel kaynak ise Anayasa'dır. Tarım toprağının korunarak kaybının önlenmesi ve beslenme ihtiyacının sağlanması konularının hüküm altına aldığı ilk Anayasa 1961 yılında yürürlüğe giren düzenlemedir. Anayasa'nın 37. ve 52. maddelerince, "Devlet, toprağın verimli olarak işletilmesini gerçekleştirmek ve topraksız olan veya yeter toprağı bulunmayan çiftçiye toprak sağlamak amaçlarıyla gereken tedbirleri alır. Kanun, bu amaçlarla, değişik tarım bölgelerine ve çeşitlerine göre topră̆ın genişliğini gösterebilir. Devlet, çiftçinin işletme araçlarına sahip olmasını kolaylaştırır" (Resmi Gazete 1961a). "Devlet, halkın gereği gibi beslenmesini, tarımsal üretimin toplumun yararına uygun olarak arttırılmasını sağlamak, topră̆ın kaybolmasını önlemek, tarım ürünlerini ve tarımla uğraşanların emeğini değerlendirmek için gereken tedbirleri alır" (Resmi Gazete 1961b).

En son kabul edilen 1982 Anayasası'nda ise topraksız çiftçiye dağıtılan toprakların bölünemez ve mirasçılarının dışında bir kimseye devrinin yapılamayacağı yer almaktadır. "Devlet, toprağın verimli olarak işletilmesini korumak ve geliştirmek, erozyonla kaybedilmesini önlemek ve topraksız olan veya yeter toprağı bulunmayan çiftçilikle uğraşan köylüye toprak sağlamak amaciyla gerekli tedbirleri alır. Kanun, bu amaçla, değişik tarım bölgeleri ve çeşitlerine göre toprağın genişliğini tespit edebilir. Topraksız olan veya yeter toprağ bulunmayan çiftçiye toprak sağlanması, üretimin düşürülmesi, ormanların küçülmesi ve diğer toprak ve yeraltı servetlerinin azalması sonucunu doğuramaz.

$\mathrm{Bu}$ amaçla dağıtılan topraklar bölünemez, miras hükümleri dışında başkalarına devredilemez ve ancak dağıtılan çiftçilerle mirasçıları tarafindan işletilebilir. Bu şartların kaybı halinde, dağıtılan toprağın Devletçe geri alınmasına ilişkin esaslar kanunla düzenlenir" (Resmi Gazete 1982).

\subsection{Toprak Kanunu ve Yönetmelikler}

Tarımsal arazilerin miras yoluyla parçalanmalarını önlemeyi amaçlayan Medeni Kanun içindeki düzenlemeler, mirasçılardan birinin talepte bulunması halinde uygulanmakta, tarımsal işletmenin kendisine özgülenmesi isteminde herhangi bir mirasçı talepte bulunmamışsa hükümler yerine getirilememektedir (Kılic 2010). Medeni Kanun'un tarıma yönelik miras düzenlemeleri içinde yetersiz kalması nedeniyle, tarım arazilerinin parçalanmalarını önlemek amacıyla "5403 Sayılı Toprak Koruma ve Arazi Kullanımı Kanunu” yürürlüğe girmiştir.

\subsubsection{Sayll Toprak Koruma ve Arazi Kullanımı Kanunu}

Tarımsal arazilerin parçalanmalarını engellemek amacıyla 2005 yılında çıkarılan kanunda tarım arazilerin de sinıflamalar getirilerek; mutlak tarım arazisi, özel ürün tarım arazisi, dikili tarım arazisi ve marjinal tarım arazisi tanımlamaları yapılmıştır. Her ilde, valilinin başkanlığı altında Toprak Koruma Kurulları oluşturularak toprakla ilgili tüm faaliyetlerin takibinin yapılması sağlanmıştır.

\subsubsection{Toprak Koruma ve Arazi Kullanımı Kanunu Uygulama Yönetmeliği}

5403 Sayılı Toprak Koruma ve Arazi Kullanımı Kanunu'na ilişkin yürürlüğe giren uygulama yönetmeliği 15/12/2005 tarihinde yürürlüğe girmiş olup bu kapsamda genel olarak; yeter büyüklükteki tarımsal arazi parsel büyüklügünün tespiti ve toprak koruma kurulunun çalışmalarına ilişkin usul ve esasların belirlenmesi amaçlanmıştır (Resmi Gazete 2005b). "Belirlenen parsel büyüklüğü; mutlak tarım arazileri ve özel ürün arazilerinde 1 hektar, dikili tarım arazilerinde 0,5 hektar, örtü altı tarımı yapılan arazilerde 0,3 hektar ve marjinal tarım arazilerinde 2 hektardan küçük olmamak kaydı ile tarım makinelerinin arazi bozulmasına neden olmadan verimli çalışmasını mümkün kılacak büyüklükte oluşturularak kullanılır. Tarım arazileri bu büyüklüklerin altında ifraz edilemez, bölünemez" şeklinde sınırlandırmalar getirilmiştir (Resmi Gazete 2005c). 


\subsubsection{Sayll Toprak Koruma Ve Arazi Kullanımı Kanununda Değişiklik Yapılması Hakkında Kanun}

$\mathrm{Bu}$ kanun 09/02/2007 girmiş olup kanunun getirdiği gelişmeler incelendiğinde; mutlak tarım arazilerinin bölünemez parsel büyüklüğünün 10 dekardan 20 dekara çıkarıldığ 1 görülmektedir ."Bölünemez büyüklükteki tarım arazilerinin mirasa konu olmaları ve üzerlerinde her ne şekilde gerçekleşmiş olursa olsun birlikte mülkiyetin mevcut olması durumunda, bu araziler ifraz edilemez, payları üçüncü şahıslara satılamaz, devredilemez veya rehnedilemez" (Resmi Gazete 2007b).

\subsubsection{Sayll Toprak Koruma ve Arazi Kullanımı Kanununda Değişiklik Yapılması Hakkında Kanun}

Toprak Koruma ve Arazi Kullanımı Kanunu'nda yapılan son yasal düzenleme 2014 yılında yürürlüğe giren 6537 Sayılı Kanundur. Kanun; asgari tarımsal arazi ve yeter gelirli tarımsal arazi büyüklüklerinin belirlenerek, bölünmelerinin önlenmesini amaçlamaktadır (Resmi Gazete 2014d).

Bölge farklılıkları göz önünde bulundurularak il ve ilçelerin arazi büyüklükleri kanunun ekli (1) sayılı listesinde verilmiştir. Listede belirtilmiş olan arazi sınırlılıkları, eşik sınır olup bu sınırın (büyüklüğün) daha aşağısındaki bir büyüklüğe yol açacak parçalanma söz konusu değildir (Anonim 2014). Mirasa konu olan tarımsal arazi ve "yeter gelirli tarımsal arazilerde" mülkiyetin devri esas tutularak, tarımsal taşınmaz mülkiyetin ilişkin usul ve esasları bu kanun içinde belirlenmiştir.

$\mathrm{Bu}$ kanunun öne çıkan en belirgin özelliği ise Medeni Kanun'da yer alan tarımsal taşınmazlar ile ilgili düzenlemelerin, 6537 sayılı kanununun içine taşınarak mülgaya bırakılmasıdır. Böylelikle miras yolu ile arazi bölünmeleri konusunda bütünlük sağlanmaya çalışılmıştır.

\subsubsection{Tarımsal Arazilerin Mülkiyetine İlişkin Yönetmelik}

Tarımsal arazilerin miras ile ilgili düzenlemelerinin ele alındığı son yönetmelik ise; 6537 Sayılı Kanun'un ardından 2014 yılında uygulanmaya giren "Tarımsal Arazilerin Mülkiyetine İlişkin Yönetmeliktir. Yönetmelik kapsamında; tarımsal arazilerin devri, miras yolu ile intikali, değerlemesi, yeter gelirli arazi büyüklüğü ve ekonomik bütünlügüne ilişkin hükümler ile ehil mirasçıya ait niteliklerin belirlenmesine ilişkin usul ve esaslara yer verilmiştir (Resmi Gazete 2014e).

\subsection{Arazi Toplulaștırma Faaliyetleri}

Tarım topraklarının parçalanmasının önlenmesi yanında parçalı arazilerin toplulaştırılması da sağlı tarım işletmesi oluşturma açısından önem taşımaktadır. Dar anlamda, küçük ve dağınık şekildeki toprak parçalarının birleştirilmesi olarak ifade edilen Toplulaştırma faaliyeti, geniş anlamda ise küçük ve dağınık şekildeki toprak parçalarının birleştirilmesi yanında küçük işletmelerin optimum çalışabilir işletmeler haline getirilmesi ve bu amaçla gerekli toprak ve su önlemlerinin alınması olarak tanımlanabilmektedir.

Türkiye'de miras hukukunun tarımda yol açtığı parçalanmaların önemli ölçüde toplulaştırma faaliyetleri ile birleştirilmeye çalışıldığı görülmektedir.

Türkiye'de ilk kez 1961 yılında arazi toplulaştırma çalışmaları başlamış, son verilen rakamlara göre yaklaşı 5 milyon hektar alanın toplulaştırmasının yapılmıştır ( 2017).

\section{Tartışma ve Sonuç}

Tarımda miras hükümleri olarak 4721 Sayılı Medeni Kanun ile 5403 Sayılı Toprak Koruma ve Arazi Kullanımı Kanunu'nun da yer alan ilgili maddeler tarımda mirasın bölüşülmesinde uygulanmış, tarımsal nüfusun toprak üzerindeki yoğunluğunun fazla olması, bununla beraber tarım arazilerinin satı̧̧ıla ilgili yasal bir denetimin olmaması toprağın gittikçe daha fazla parçalanmasına neden olmuştur (Gün 2001).

Toprak parçalılığının tarıma yansıyan en önemli sonucu olarak tarımda verimliliğin azalması olarak gösterilmektedir. Üretim miktarındaki azalışları da beraberinde getirirken sermaye noksanlığı yaşayan tarım kesimi için maliyet masraflarını da arttırmaktadır (Gün 2006).

Medeni Kanun'un öngördüğü tarımsal mirasın eşit paylaşımı, tarımsal toprağın korunmasını amaçlayan 2005 yılında özel düzenlemelerle yürürlüğe giren 5403 Sayılı Toprak Koruma ve Arazi Kullanımı Kanun'un miras ile ilgili hükümlerinin önüne geçmiştir. Tarımda miras ile ilgili yasal mevzuatın tarım işletmelerinin ve tarım arazilerinin parçalanmalarını önleyememesi nedeniyle 2014 yılında " 6537 Sayılı Toprak Koruma ve Arazi Kullanımı Kanununda Değişiklik Yapılması Hakkında Kanun” çıkarılmıştır. Bu kanunun yürürlüğe girmesiyle beraber Medeni Kanun içindeki miras ile ilgili kısımlar mülgaya bırakılarak, Toprak Koruma ve Arazi Kullanımı Kanunun içine taşınmıştır. Tarımda miras hükümlerinde bütünlük sağlayan bu düzenlemeyle birlikte mirasa konu olan tarımsal arazi ve işletmenin mülkiyetinin devri esastır. Mülkiyet işlemleri ile ilgili sürecin mirasçıların isteğine bırakılmayarak, devir işlemlerinin kanunun yürürlüğe girdiği tarihten itibaren en geç bir yıl içinde tamamlanması öngörülmüştür. Mirasçılar arasında anlaşma sağlanamadığı takdirde ise mirasçılar tarafindan yetkili sulh hukuk mahkemesi nezdinde dava açabileceklerdir. Dava sonunda hakim kanun gereği en uygun gördüğü kişiye tarımsal varlığın devrini gerçekleştirecektir. Mirasa konu olan tarımsal işletmenin kendisine devrini talep eden mirasçı bulunmadı $\breve{g}_{1}$ takdirde ise hakim üçüncü bir kişiye satışına karar vererek bu suretle yapılacak satış sonucu elde edilen gelir, mirasçılara payları oranında paylaştırılacaktır.

Sonuç olarak; tarımsal mirasın mülkiyeti ile ilgili usul ve esasları tek bir çatı altında toplayan 6537 Sayılı Kanun, yürürlüğe girdiği tarih itibariyle yeni sayllacak bir düzenleme olup kanundan sonra gelen miras yoluyla intikallerin sayıları henüz belirlenmemiştir. Ancak kanunun maddeleri incelendiğinde diğer mirasla ilgili yasal düzenlemelere göre daha kapsamlı bir çalışma olduğu ifade edilebilir.

\section{Kaynaklar}

Aksoy S (1984) Tarım Hukuku, Ankara Üniversitesi Ziraat Fakültesi Yayınları: 907, Ders Kitabı: 254, Ankara, s. 213-223.

Anonim (2006) “Tarım Kanunu (5488)", Tarih: 25.04.2006, Say1: 26148, Ankara.

Anonim (2014) Kalkınma Bakanlığı. "Tarım Arazilerinin Sürdürülebilir Kullanımı Çalışma Grubu Raporu”, Yayın No: KB: 2860-ÖİK: 714, Ankara, 2014.

Demirtaş E, Sarı M (2003) Arazi toplulaştırması, BATEM, Derim, Cilt: 20(1), s. 48-58.

Ekinci K, Sayılı M (2010) Tarım arazilerinin parçalanmasını önlemeye yönelik mevzuat üzerine bir inceleme, GOÜ Ziraat Fakültesi Dergisi, Cilt: 27(2), s. 121-129.

GTHB (2017) http://www.tarim.gov.tr/Konular/Arazi-Toplulastirma-ve- 
Tarla-Ici-Gelistirme/Projeler. Erişim 15 Eylül 2017.

Gün S (2001) Türkiye'de tarım topraklarının mülkiyet durumu ve uygulanan politikalar, Cumhuriyetin 100. Yılında Türk Tarımının Hedefleri Sempozyumu, s. 325-336, Ankara.

Gün S (2006) Tarımda toprak mülkiye yapısı ve işletmelerin iyileştirilmesi, Türk Tarım Dergisi, Sayı: 171, s. 34-37.

Kılıç M (2010) Avrupa Birliği’ne uyum sürecinde Türk tarım hukuku: mevcut durum, son gelişmeler ve yaklaşımlar. Ankara Avrupa Çalışmaları Dergisi, Cilt: 9, No: 2, s. 67-92.

Resmi Gazete (1926a) Medeni Kanun. 04/04/1926-753/598 madde.

Resmi Gazete (1926b) Medeni Kanun. 04/04/1926-753/599 madde.

Resmi Gazete (1926c) Medeni Kanun. 04/04/1926-753/600 madde.

Resmi Gazete (1961a) 1961 Anayasası. 31/05/1961/37 madde.

Resmi Gazete (1961b) 1961 Anayasas1. 31/05/1961/52 madde.

Resmi Gazete (1982) 1982 Anayasası. 20/11/1982/44 madde.

Resmi Gazete (2001) Medeni Kanun, No: 4701 - 2001.Md.973-1030. 08.12.2001/ Say1: 2460 .

Resmi Gazete (2005a) Toprak Koruma ve Arazi Kullanımı Kanunu, No: 5403 - 05. 19.07.2005/25880.

Resmi Gazete (2005b) Toprak Koruma ve Arazi Kullanımı Kanunu Uygulama Yönetmeliği, 15/12/2005/1 madde.

Resmi Gazete (2005c) Toprak Koruma ve Arazi Kullanımı Kanunu Uygulama Yönetmeliği, 15/12/2005/11 madde.

Resmi Gazete (2007a) Toprak Koruma ve Arazi Kullanımı Kanununda Değişiklik Yapılması Hakkında Kanun, No: 5578 2007. 9.02.2007/26429.
Resmi Gazete (2007b) Toprak Koruma ve Arazi Kullanımı Kanununda Değişiklik Yapılması Hakkında Kanun, No: $5578-$ 2007. 9.02.2007-5578/2 madde.

Resmi Gazete (2014a) Toprak Koruma ve Arazi Kullanımı Kanununda Değişiklik Yapılması Hakkında Kanun, No: 6537-2014. 15.05.2014a/Sayı: 29001.

Resmi Gazete (2014b) Tarımsal Arazilerin Mülkiyetinin Devrine İlişkin Yönetmelik, 2014. 31.12.2014/29222.

Resmi Gazete (2014c) Toprak Koruma ve Arazi Kullanımı Kanununda Değişiklik Yapılması Hakkında Kanun, No: 6537 201430/04/2014-6537/9 madde.

Resmi Gazete (2014d) Toprak Koruma ve Arazi Kullanımı Kanununda Değişiklik Yapılması Hakkında Kanun, No: 6537 201430/04/2014-6537/1 madde.

Resmi Gazete (2014e) Toprak Koruma ve Arazi Kullanımı Kanununda Değişiklik Yapılması Hakkında Kanun, No: 6537 - 31/12/2014Say1 29222/1 madde.

Sayın C (2015) Akdeniz Üniversitesi Ziraat Fakültesi Tarım Ekonomisi Bölümü, Tarım hukuku ders notları, Antalya.

TİKAS (2015)

http://www.tuik.gov.tr/arastirmaveprojeler/tikas/tikas.html\#panel-1. Erişim 19 Haziran 2015.

TÜİK (2006) http://www.tuik.gov.tr/VeriBilgi.do?alt_id=1003. Erişim 22 Haziran 2015. 